\title{
Open and Flowing: The Design of an Interactive Space at the Marketplace
}

\author{
Alfansyah Fauzy Prajawisastra ${ }^{1}$, Tutin Aryanti $^{1 *}$, and Restu Minggra ${ }^{1}$ \\ ${ }^{1}$ Universitas Pendidikan Indonesia, Department of Architectural Education, J1. Dr. Setiabudi No. 207, Bandung, Indonesia 40154
}

\begin{abstract}
Most traditional market revitalization concepts only focus on buying and selling activities while putting aside the fact that Indonesian traditional markets have social potentiality. This article aims to explore the interactive concepts to be implemented in the redesign of the Sederhana Market, Bandung, Indonesia. The study employed literature review and case study to generate the concepts of interactive space in a marketplace. It finds that interactiveness can be implemented in the open building massing, including the use of transparent partitions, inclusive accessibility for all users, and open circulations. The program is arranged to accommodate users' interactions, zoning according to functions, management objectives, and economic accessibility. It also provides community spaces located on every floor, adequate lighting and airing in all market spaces, easy and low-cost maintenance, and signages that allows communicable spatial layout. The Sederhana Market redesign is expected to improve the quality of the marketplace environment, maximizing the economic functions, while flourishing social interactions among users.
\end{abstract}

\section{Introduction}

Nowadays many traditional markets are started and have been revitalized, from the many traditional market revitalization concepts that have been done, this revitalization has changed the market conditions become cleaner, orderly, and has supporting facilities, from the toilet and mosque [1]. But most of the revitalization concept focuses only on buying and selling activities

This revitalization program is initiated with the intention of responding to the chronic problems of traditional markets in Indonesia, which are portrayed as a slum, dirty, muddy, unkempt, and have a quality of occupancy very low [2]. Even for PD. Pasar Bermartabat has a vision and mission that one of the contents is the market aims as an object of development in the field of market management and in the field of goods and services business related to market management by applying the principles of good corporate governance [3]. However, researchers have not examined the interactive elements that occur in the market. In fact, traditional markets in Indonesia have social potential. It is a means of people to be able to socialize, meet each other, such as between traders and sellers, the social potential can be seen from the way of transactions commonly done in traditional markets, The traditional market has its uniqueness in the transaction that is with the process of bargaining a price so that the satisfaction of individual, both sellers and buyers [4].

This article examines how the implementation of an interactive space theme in traditional markets when viewed from it, bargaining is a process of interaction between traders and buyers conducted in one of the public spaces of the traditional market, Traditional market is inseparable from the society's life. Traditional market is also a public space that becomes the city's identity [5].

This article uses a performance approach referring to the Indonesian National Standard (SNI).to provide a solution to traditional market problems. This article contributes to enriching the design of a traditional market as an interactive space, and thus, providing architects and governments with inspirations on marketplace revitalization and redesign.

\section{Design method}

This study uses a performance approach in redesigning traditional markets. This approach serves as a basis for exploring the problems found in the Sederhana Market. The performance refers to the SNI (Indonesian National Standard) (Fig. 1).

\footnotetext{
$\overline{\text { * Corresponding author: tutin@upi.edu }}$
} 

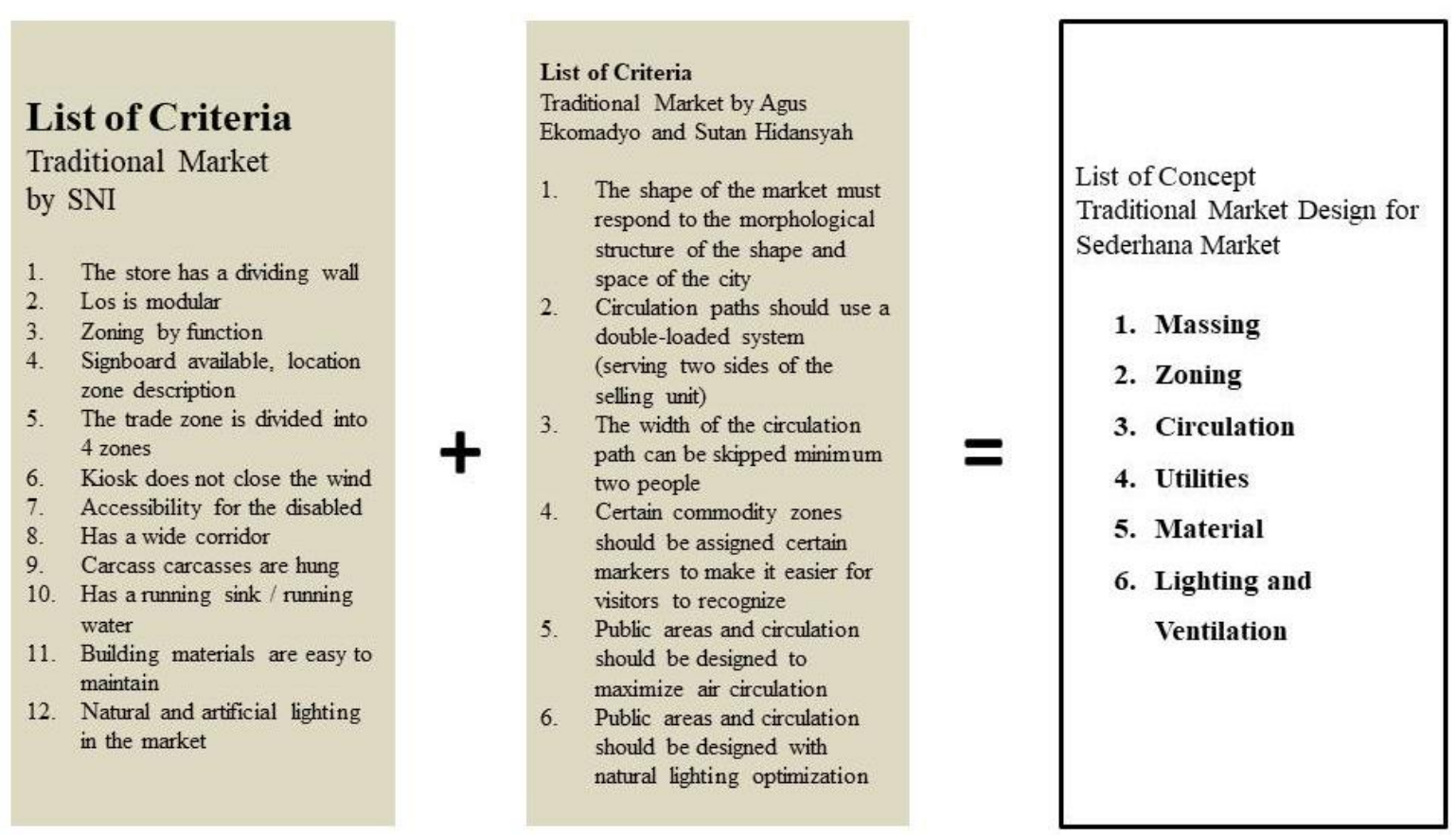

Fig. 1. Redesign concept, based on the list of SNI criteria on traditional market (A.S. Ekomadyo and S. Hidayatsyah).

\section{Concepts and design}

The market is always a space of interaction for the community. The interaction is present when buyers and sellers and other market users meet each other, ranging from asking goods to the bargaining process. The market has become a socio-cultural space for the community; a successful market is a market that is bustling by economic activity and social, which is characterized by the availability of comfortable, accessible spaces, and a container of socio-cultural activities [2]. Most Indonesian traditional market is dirty, muddy and humid. A well-designed market will accommodate convenient and accessible shopping and encourage more social interaction.

Pasar Sederhana (the Sederhana Marketplace) is located in the heart of Bandung, West Java (Indonesia). It serves the northern city area and provides daily goods, vegetables, fruits, cookies, fashion, and simple kitchen appliances. While the market is located on a secondary intersection, it is also challenged by the heavy traffic surrounding the site and the temporary flooding that sometimes takes place due to heavy rains.

Some studies have identified the role of space in encouraging or discouraging social interaction in the community. For example, Agustina and Beilin found that multicultural interactions took place in a community garden that was designed to facilitate such interactions, and thus encouraged a community that is more respectful to diversity [6]. The vibrant social interactions in the community indicate a good quality of life $[7,8]$ The involving factors are spatial continuity and accessibility, people's activity, comfort, and attraction of the spaces $[9,10]$.

The interactivity theme is inserted to the redesign of Pasar Sederhana through building mass composition, zoning, circulation, building utility and materiality, and ventilation and lighting. The basic idea is to allow inclusive accessibility, informative layout, spatial continuity through flowing circulation and visual continuity among vertical levels, and more importantly, the provision of more spaces for social interaction.

\subsection{Building massing}

The basic proposed market building is rectangular in shape, considering its optimal effectiveness of the use of space. The rectangle is transformed through subtraction and addition in accordance with the market's open character (Fig. 2). The modified form is divided into two masses with a pedestrian corridor in between. This modification is aimed to avoid a gigantic and massive building impression. In addition, this also allows better light penetration, thus making natural lighting possible, and cross ventilation for natural airing.

\footnotetext{
*Corresponding author: tutin@upi.edu
} 


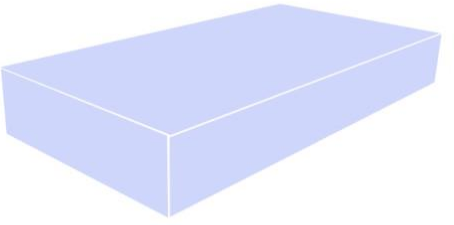

Mass Building rectangle is a good mass for the market because the building should facilitate the modular stall / kiosk

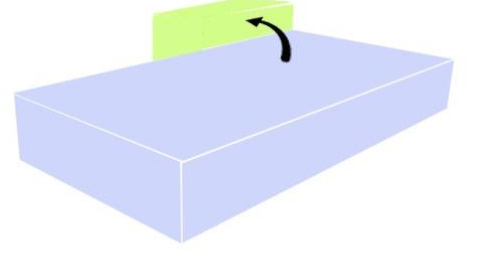

Given the addition of mass in the north, to strengthen the main facade.

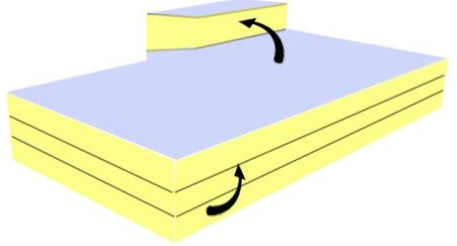

The mass of the building is divided into 4 floors

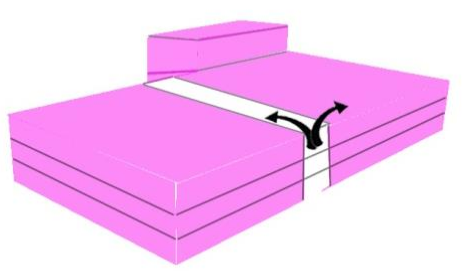

to eliminate the impression of a thick building. the mass of buildings finally divided into two mass

Fig. 2 Building massing concept.

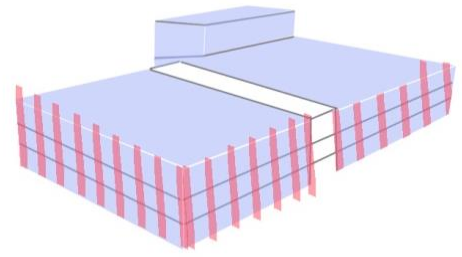

exposed columns and the roof of the fungus to remove the monotonous impression on the building

\subsection{Building zoning}

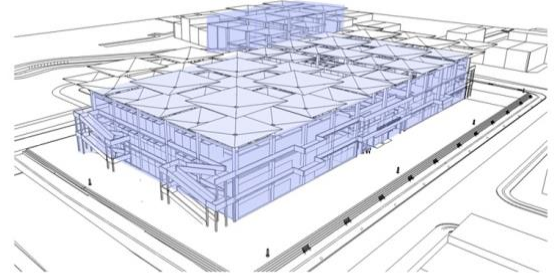

Ramp on the exterior becomes an exposed access point for people visiting the market

Ground Floor
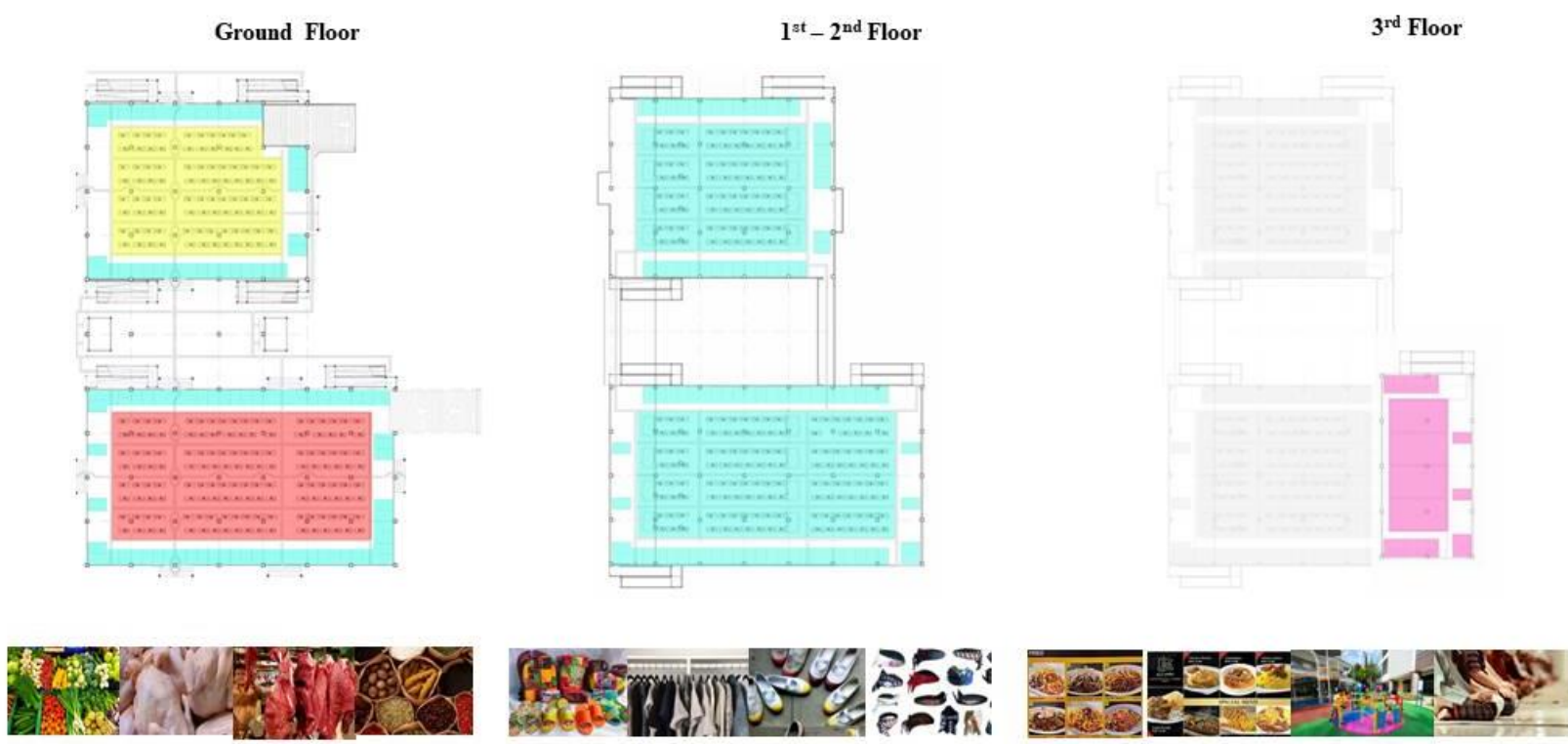

Fig. 3. Building zoning.

The building is divided into 4 zones based on the commodities sold. They are commodities (shown in blue), wet commodities (shown in yellow), fast food (shown in purple), and fruit and vegetables (shown in red) (Fig. 3). Such zoning is intended to facilitate consumers with a more informative shopping, to simplify the future market maintenance due to each commodity's specific needs and treatments.
To facilitate the commodification of the commodities, the four commodities are divided based on the colors applied in the market void which also serves as a place for the users to sit and to interact with each other, as well as wayfinding for market users. 


\subsection{Building circulation}

The market circulation is an important point. Every zone must have a good circulation path and is easily accessible to anyone. All facilities must be accessible and utilized by all people, including the disabled and the elderly [11].

To support a good circulation in the market, the market corridor that was 1.8 meter in width was changed into $2.4 \mathrm{~m}$, to accommodate buying and selling activities as well as interactions among sellers without obstructing other market users' movement (Fig. 4). The use of tactile block paving and the integrated ramp from pedestrian ways facilitate access for disabled people. All these will support the interactive market criteria where all visitors from various circles can easily visit the market.

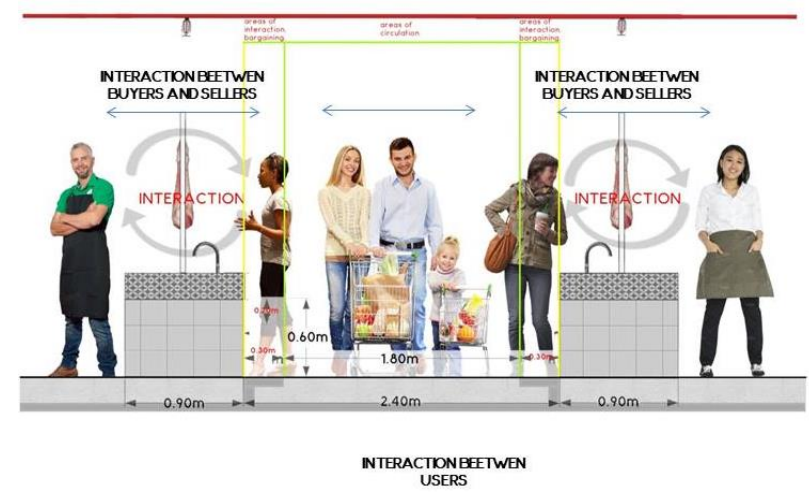

Fig. 4. Circulation area to improve interaction.

\subsection{Building utility}

Building utilities are significant in a market design because good utilities will help to keep the market to stay in good condition, in addition to making the maintenance required in the market utility easier (Fig. 5).

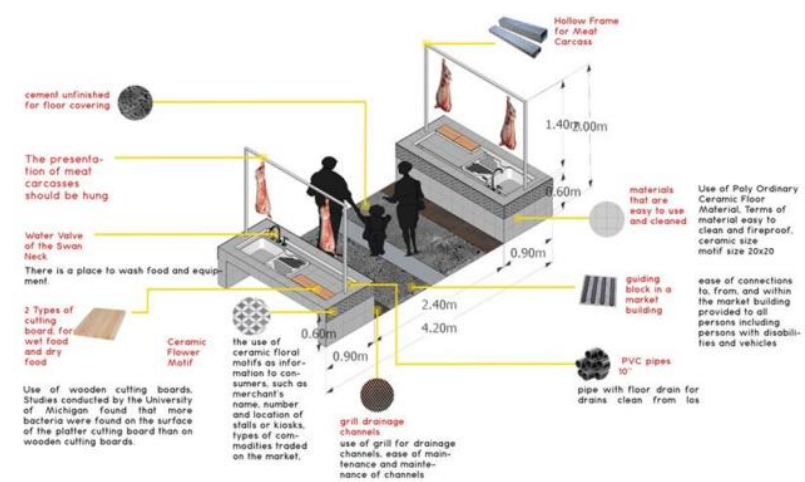

Fig. 5. Utility concepts.

\subsection{Material}

Building materials are carefully selected for the market design. It should be easily handled and maintained. [11]. Long lasting material characters can also support interactive concepts, such as the use of colored ceramics that are easy to clean, also has a color function can distinguish the zonation as well as the identity of the market itself.

\subsection{Lighting and ventilation}

The market building should have sufficient openings. Good and adequate openings will provide good air circulation and lighting to the market. This will certainly affect the users' health and mood of shopping and interact with the others. Buildings must have natural or artificial ventilation by its function [11]. This redesign proposes the use of voids in the middle of the building for air circulation and lighting, in addition to visual continuity. Moreover, the wall consists of hollows where fresh air and lights can penetrate.

\section{Conclusion}

The redesign of Pasar Sederhana taking its function not only as a center for economic activity but also as a social and cultural center. The redesign, through the concept of hollow building masses, flowing circulation and spatial continuity, the use of color for signage, informative zoning, and inclusive accessibility, promises a space that accommodates and further encourages social interaction.

\section{References}

1. E. Masitoh, Upaya Menjaga Eksistensi Pasar Tradisional: Studi Revitalisasi Pasar Piyungan Bantul, PMI, 63-78 (2013)

2. A. Ekomadyo, S. Hidayatsyah, Isu, Tujuan, dan Kriteria Perancangan Pasar, Prosiding Temu Ilmiah IPLBI, 1-5 (2012)

3. P. K. Bandung, Maksud dan Tujuan PD Pasar Bermartabat (2016) Retrieved May 1, 2018, from PPID Kota Bandung: https://ppid.bandung.go.id/knowledgebase/visi-danmisi-pd-pasar-bermartabat/

4. M. Chandra, K. Santoso, Pasar Tradisional - Modern Surabaya, Dimensi Arsitektur, 1-6 (2012)

5. D. Fitria, A Modern Vibe: The-redesign of Traditional Market, IOP Conf. Ser.: Mater. Sci. Eng. 288, 012043, 1-5 (2018)

6. I. Agustina, R. Beilin, Community Gardens: Space for Interactions and Adaptations, Procedia - Social and Behavioral Sciences, 36, 439 - 448 (2012)

7. D. Das, Urban Quality of Life: A Case Study of Guwahati, Springer Science+Business Media B.V., Soc Indic Res., 88, 297-310 (2008)

8. A. D. Nasution, W. Zahrah, Community Perception on Public Open Space and Quality of Life in Medan, Indonesia, Procedia - Social and Behavioral Sciences, 153, 585-594 (2014)

9. M. Moeini, Attitudes to Urban Walking in Tehran, Journal of E\&PB, 39, 344 - 359 (2012)

10. N. K. Mamaghani, A. P. Asadollahi, S. R. Mortezaei, Designing for Improving Social Relationship with Interaction Design Approach, Procedia - Social and Behavioral Sciences, 377-385 (2015)

11. B. S. Nasional, SNI Pasar Rakyat. Jakarta: Badan Standar Nasional. Utaberta, N. Pencarian bentuk 
arsitektur Islam yang berbasiskan nilai. Paksi

Jurnal, 38-53 (2015) 